\title{
Julian Meyrick
}

\section{Does culture need explaining?}

This paper was delivered on 26 November 2012 as a Keynote Address for Encounters: Place/Situation/Context, the 17th Annual Conference of the Australasian Association of Writing Programs, Deakin University, Waterfront Campus, 25-27 November 2012

Abstract

This keynote paper focuses on the relationship between the idea of culture and the different ways it is talked about in the contemporary world. The media, the Academy, the creative professions and public policy all provide different discursive regimes in which key terms describe and evaluate artworks and cultural experiences. Words are shared but their context of use is not. We think (as critics, academics, artists and policy-makers) we are talking about the same thing, equal participants in 'the rhetorical economy'. But in reality we occupy radically different subject positions. Referencing Matthew Arnold's Culture and Anarchy, the paper teases out the implications of functional cultural provision for one area in particular: the 'fit' between the categories of government policy and the idiosyncratic processes of creative practice. Can the state define culture save as a general figure? Can it measure artistic value in any but an aggregate way? What are the implications for the language of cultural reporting, and the relationship between the artist and the state, with the 'cultural industries' now representing 3.6\% of Australia's GDP?

Keywords: culture, cultural policy, creative practice

When we stand in front of a painting; when we read a novel or a poem; when we go to a concert or a dog show or participate in a recreation of a medieval tournament; is there anything to be saidabout these experiences? If so, for what end and to whom? How do our words stand in conjunction to our cultural encounters? Reflection? Interpretation? Assessment? Sometimes we may want to speak of the art around us, using key terms to express what we feel to be its chief value. What forces pronounce that which, until then, is silence sufficient unto itself? What are the politics of explanation, the formations by which our words are aggregated and deployed as a plural figure? 'Does culture need explaining?' A small door that opens onto a large room. For behind the methodological and epistemological subtleties stand visceral emotions: confusion, frustration, anger, and despair. Especially the last. Especially despair. 
In this paper I talk about talking about culture, about the circumstances whereby the individual experience of art becomes de-singularised and framed as something we can discuss without sharing that individual experience. This sort of general accounting happens a lot in life, so in one way why should art be excepted? In another, it raises problems about intended meaning. Most of the time these may not be important problems. Some accounts of art are throwaway and slight. Pick up any festival play program. Is it possible for so many outstanding, provocative, cutting-edge productions to be gathered in one place, again? If governments were to levy a tax on adjectives in arts brochures, budget deficits would be a thing of the past. We screen this talk out as background burble, something that contextualises but does not define, the artistic experience itself. On other occasions, however - when critics turn-in contentious reviews, when artists apply for a vital grant, when communities strive to retain a cultural event that has hitherto defined them, or when we, as individuals, seek a hold on the world through art that is an essential part of being human - the right words are required. The health of the rhetorical economy makes a difference when we are faced, as we are all faced sooner or later, with choices that really matter.

When words fail art, the results can be catastrophic. My life has been spent working with, studying and writing about theatre artists. When I began postgraduate research in 1992, I read John West's colourful history of the Australian stage (West 1978). One story in it suggests my motivation for trying to understand talk about culture. It involves a married
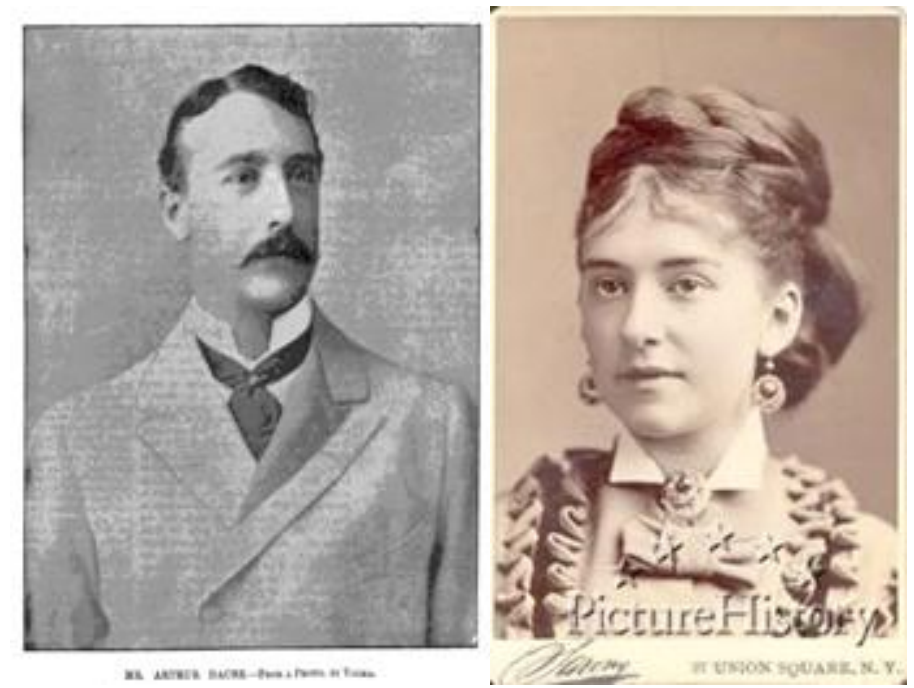

Figures $1 \& 2$. Arthur Dacre and Amy Roselle

couple, Arthur Dacre and Amy Roselle, middle-ranking actors who emigrated here in 1895, she more talented than him, the timing of their arrival not great, the summer weather hot, their shows poorly received. Her Majesty's Theatre, on the corner of Sydney's Pitt and Market Streets, where they performed, is now Centrepoint Tower. They lived in a boarding house in Macquarie Street where West says, 'their money troubles were pressing, their commitments compounding, their continued failures disheartening' (92). Like many artists past and present they felt a disconnection between what they were trying to do and what was wanted of them. Arthur complained he was expected to memorise too many lines too quickly and was sharply told that any competent Australian actor would have learned them beforehand.

I will leave Arthur and Amy there, struggling, as I analyse the problems culture presents as a discursive figure. I bring them up as a warning that the risks of art can be considerable. It is the job of art talk to clarify this risk, plumb it, narrate it. It is not the job to emulsify it in a 'cultural function' that, like water from a 
tap, is presumed to flow at a twist of a wrist, the only issue being how far to turn that tap. This is how culture is typically framed in the policy sphere, where much discussion about art's public benefit gets done. Arthur and Amy remind us that underpinning what the Australian Bureau of Statistics dub 'the cultural industries' are lives both fragile and unique. This is the essence and engine of any cultural encounter: one human being communicating, through art, to another. How can we have forgotten this? In a connected world, with more ways of talking to each other than ever before, how has the talk around art got so congested and confused? Yes, definitions of culture have expanded, but this phenomenon has been going on for over a hundred years. Why has this ubiquitous social fact led to such a corrosion of common understanding? I am not being provocative. Along with my study of Australian theatre has been a parallel project: the study of the cultural policies that have, since the 1940s, conditioned its trajectory. And here we find a language so removed from the singular act of cultural exchange as to appear a fugue, disjunctive consciousness, an alien lingo, riddled with phrases through which art drops from view like a body down a mine shaft. If this feed-source to the rhetorical economy is allowed to run unchecked, what happens to our own talk about art? What happens when we say, feebly, 'I rather liked it' or 'it's just something I want to do' or 'it's only a hunch'? What hope do we have faced with a perfect storm of specialised jargon that rules our testimony out of court as anecdote, hearsay, commonplace evidence? If we are not careful we shall find ourselves, like Arthur, with words escaping our grasp.

\section{Four Ways of Talking about Culture}

Like load-bearing columns, there are four areas in which culture gets spoken about, four discursive regimes: the media, the Academy, the creative professions and public policy. If I were to show examples of art talk there would be little trouble identifying their respective domains. However, there is deal of fluidity between them, and considerable overlap of personnel. The New Wave director Rex Cramphorne, founder of the legendary Performance Syndicate, was also the Bulletin theatre critic. The historian Don Watson was also the architect of Creative Nation 1994), Australia's first bona fide cultural policy. Pete Garrett, lead singer of the band the Midnight Oils was, from 2007 to 2010, Federal Minister for the Arts. Partly because of this on-going boundary crossing, the regimes themselves are unstable. Are Cramphorne's submissions to the Australia Council in the 1970s grant applications or artistic manifestos? Are James Waites' reviews for New Theatre Australiain the 1980s critical opinion or cultural theorising? Is my book on the Nimrod theatre (Meyrick 2002) academic analysis or a practitioner's guide to how a company works? The bleeds between different ways of talking are inevitable if the perspectival shuffling needed to unite our singular experience of art with a more general vista is to be successful. Different regimes acquire conventions that change over time. In the 1990s we knew what to expect from a theatre critic, roughly. When blogs came along a decade later, the domain took another direction, reshaping critical conventions and our expectations of them.

It is the shifting intersections of these descriptive registers that creates what might be called 'the rhetorical economy', the galaxy of words that pronounces our experience of art and public perceptions of its value. Art and talk about art are separate but linked phenomenon. This makes the operation of cultural markets difficult to predict, as every gallery owner or would-be best-selling publisher knows. The economist David Throsby, whose work on the application of contingency value methods (CVM) to the pricing of cultural goods is among the most sophisticated, speculates about co-existent markets, 
where the established value of an artwork is subject to multiple, parallel judgements that are continually revising it (Throsby 2002). Masterpieces are ruled minor works. Dreary nights in the theatre are declared historic events. Or markets split. Playwrights like Daniel Keene are programmed by companies in France, but cannot get a gig back home.

We can say, our talk reflects these tensions and manoeuvres. But equally it fuels them. Different discursive regimes have different contexts, and natural language is lexical in its denotative purchase. When key terms are catapulted into public use they are taken out of their original groove and assume the status of free-floating interpretive ideas, or metaphors of command. A practitioner's idea of 'good' art is different in experiential vista from that of a policymaker's, not just because they are different people but because the position of the descriptor stands in different relation to its empirical referent. For artists, 'good' is an inductive conclusion or empirical generalisation, a result of looking at examples of art and drawing out the relevant features. For arts bureaucrats it is a nomothetic category, a value anterior to the practices of the field, which it must inform and shape. Typically, key words sweep out a range of meanings, a bundle of tasks, which vary their application further. But the words themselves don't change, and so their use by different speakers promulgates considerable anxiety within the rhetorical economy. What are sometimes called operators of capture - 'excellence', 'innovation', 'creativity' and so on - exist as terms both committed and risible. However convincing they may be when linked to a singular experience of art, they become controversial and opaque when taken up in general talk about culture. And this is reflected in regular wrangles about terms and definitions that pepper the history of the sector as a whole. In the theatre the most obvious collisions are those between critics and practitioners. What is a good play? What kind of stage experiences can be called good? Can be called a play at all? Such foundational questions have fuelled famous critical controversies from Henrik Ibsen's Ghosts to Sarah Kane's Blasted. John McCallum's 'Some Preoccupations of Australian Theatre Criticism 1955-1978' (1981), an unpublished thesis that deserves to be better known, examines the media reception of New Wave drama in the 1970s and provides signal examples of discursive abrasion as its aesthetic sensibility sought acceptance on its own terms. This reached a peak in the middle of the decade with altercations around Alex Buzo's dramas, Martello Towers and Makassar Reef, and the appearance of a new generation of reviewers, including a raft of practitioner-critics in the magazine Theatre Australia, that opened the way for a renovation of key terms and semantic associations. In 2009, I was involved in my own stoush with critics over a production of Harold Pinter's The Birthday Party I directed with an Aboriginal cast (Meyrick 2010). This fracas which ended up on the pages of the UK press, was deplored by some as unnecessarily adversarial. But history gives the lie to this. Critics and artists do not share the same experiential vista. A theatre production for the former is one of a number of similarly distanced objects arrayed for comparative assessment. For the latter, it is a singular creation, a unique expression of imagination and effort. The two regimes do not share an identity of interests and the struggle around language is part of a necessarily prickly cohabitation.

The same is true of the relationship between the profession and the Academy. Rustom Bharucha's criticisms of Peter Brook's production, The Mahabharata, are a rebuke to the arrogance of theatre directors in appropriating the religious texts of other cultures for their own ends. His article, 'A View from India' (Bharucha 1988) is largely a reflection on language, how little Brook understood of the Hindu context of his sacred texts and how little he cared to. Brook wanted a 'good' play, a stage work consonant with the features of other 'good' plays he had seen or directed. For Bharucha this goal is both not enough 
and beside the point. That The Mahabharata was celebrated all over the Western world as a landmark work only made the situation worse, given Brook's lack of comprehension of his source culture. Bharucha's chosen instrument of account was the scholarly essay, and he uses this to point out where the show erred according to a more immediate cultural and religious perspective. It is an elegant analysis, all the more telling for its considered restraint. Brook's reputation has never recovered, and the intercultural theatre project with which his later career is associated found itself framed in a decidedly crypto-colonial light.

And so on. The struggles between different discursive regimes feeds into the rhetorical economy, refining key terms and absorbing new vistas wherein their use makes public sense. Critics, scholars and artists knock against each other in lively debate and the semantic associations of ambiguous descriptors are disciplined in the application. There is no given order of precedence. A rough, combative equality of authority exists between the three domains. Dominant figures are drawn from each but this does not transmute into permanent Delphic status. Just because Ken Tynan was a critic with the ability to change a nation's view of modern drama, doesn't mean there has to be another like him. Hegemonies and spheres of influence within these discursive regimes are contested and impermanent.

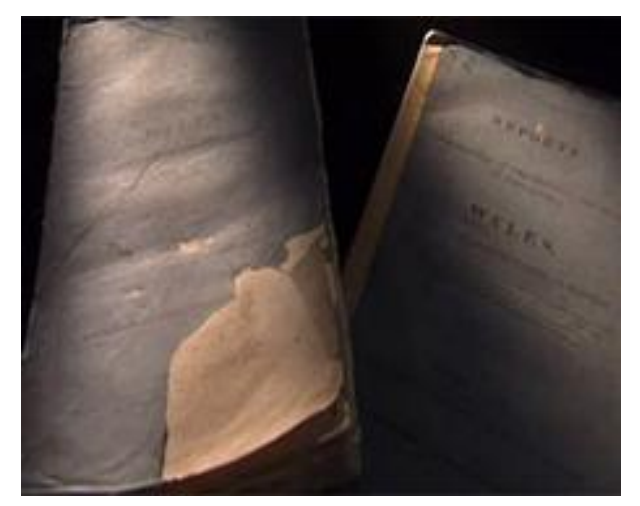

Figure 3. Blue Books, circa 1847

The fourth domain, public policy, is a different matter. It is historically the last to arrive. Scholars can trace their lineage back to Aristotle, Horace, and Longinus, media critics to Addison and Steel and the pages of The Spectator, and artists to thousands of years before any of these names. Public policy with the provision of culture as its explicit goal is a hundred and fifty years old at best, coterminous with the appearance of state educational and welfare goals in the nineteenth century. Of course, rulers were concerned with art before this, especially its political mobilisation effects. But this did not develop into a separate language. When tyrants or republicans leaders wanted to talk about art, they did what everybody else did: bone up on the classics, develop opinions in the field, engage in robust debate about particular works. The appearance of a discourse of the state changed this situation. Its register of description was an aggregate one. It de-singularised the phenomenon of art according to a rationalutilitarian logic of collective benefit by creating a new supervening construct, culture. This construct was disincarnated from any particular manifestation and discussed in the abstract, as a supplier of social effects. The properties of art had long been the object of aporetic analysis. This is different, however, from framing it as a plane of pure potentiality, without historical feature or fate. To say the discourse of the state instrumentalizes art is too simple. It subsumes it into a service-provision language dependent on the methods of aggregate evaluation. The historian GM Young in Portrait of an Age (1936) discusses the appearance of so-called 'blue books', Victorian-era exercises in social data gathering, that reactionary MPs pointedly used for pistol practice. Facts, figures 
and tables are the instruments of account here and they suit well those goods and services - art, like everything else, now conceived as a good or a service that are homogenous, divisible and substitutable. The reductiveness of this move is less important than the procedures by which it was expressed. Art was enumerated and this opened up a new world of social framing. It was the state that did the framing, and this was to have serious consequences in the totalitarian regimes of the twentieth century. But in the decades before, when the state was just putting a toe into the cultural waters, the situation appeared more benign.

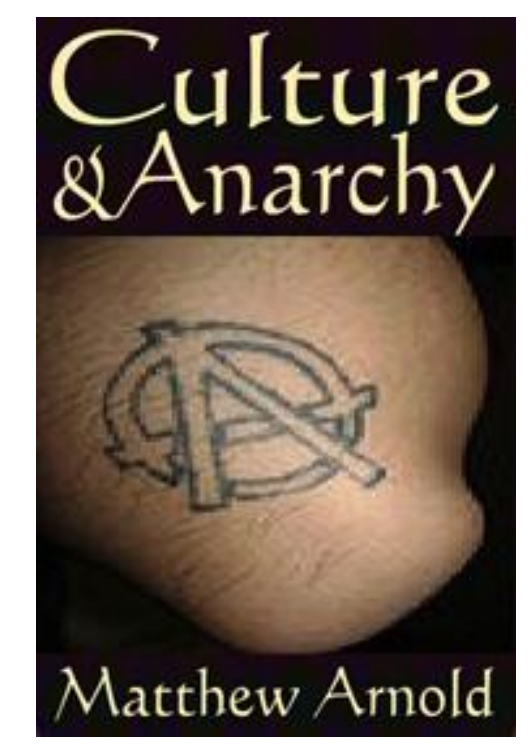

Figure 4. Culture and Anarchy cover image

Matthew Arnold's essay Culture and Anarchy published in 1867 [1], is a key moment in the birth of culture as a synthetic policy category. Arnold was one of a number of nineteenth century critics like Carlyle, Ruskin and Morris writing about art. But his ideas about it were broader and his influence more decisive. In fact, we are living in an Arnoldian world in many respects and it is surprising he has not been given more consideration by cultural studies scholars [2]. He was the son of Thomas Arnold, the clergyman headmaster of Rugby public school memorably ironised by Lytton Strachey's Eminent Victorians (1918). Matthew was concerned with education too, as a government school inspector for thirty-five years. This occupation informed his view that culture was integral to the collective self-improvement of the British middle-classes. Arnold has been called the first diagnostician of modernity (Allott 1954: 11). He saw that the modern world was a middle-class one, that this socio-economic group now possessed decisive political power. His opinion of its views and values was a low one, however, so he gave himself over as an educational propagandist, urging reform of the secondary school curriculum. Leaving aside his somewhat Grecian prose style, his concerns are congruent with any modern governments from Deakin to Gillard: belief in a broad humanism; in merit-based reward; in education as the solution to the economic and technical challenges of the future; in cooperation between different classes as necessary for the achievement of national prosperity.

Arnold was a classics scholar and a gifted poet. In public debate with Thomas Huxley, he laid out the case for arts-oriented as opposed to science-focussed schooling. His conception of culture is crucial for understanding public policy in relation to creative activity today. There are two ways of looking at culture, the broad and the narrow, culture as 'that which makes life worth living', in TS Eliot's phrase (1948), and culture as in galleries and arpeggios, culture as in art. Arnold anchored his position in neither of these. He argued culture was an expression - a key phrase this, constantly reiterated - of our 'best self', 
something both normative and empty of specific content. Culture's job was to edify, to ameliorate the crass materialism and self-interest that prevented modern Britons from attaining, in another oft-repeated phrase, 'sweetness and light'. Of course, as a literary man Arnold had opinions about what activities this entailed. But these were left unstated, thus splitting his idea of culture from its empirical ground and turning it into an immanent figure of social order. The relationship between culture and its category became parasitic, relying on an assumed context that could not be openly admitted to. And who would manage this treacherous lack of feature, this open but selective understanding of culture? The answer makes Arnold the progenitor of social conceptions of cultural benefit, the father of cultural policy. A crucial passage from Culture and Anarchy reads:

By our best self we are united, impersonal, at harmony... And this is the very self which culture, or the study of perfection, seeks to develop in us, at the expense of our old untransformed self, taking pleasure only in doing what it likes or is used to do, and exposing us to the risk of clashing with every one else who is doing the same! So that our poor culture, which is flouted as so unpractical, leads us to the very ideas capable of meeting the great want of our present embarrassed times. We want an authority, and we find nothing but jealous classes, checks and a deadlock; culture suggests the idea of the State. We find no basis for a firm State-power in our ordinary selves; culture suggests one to us in our best self. (Arnold 1987: 96, original emphasis)

Arnold's panegyrics on the power of culture are also promotions of the power of the state. Imelda Palmer observes, 'basically what he proposed was a transformed State with executive power vested in the collective best self' (Palmer 1979: 49). In his job as a school inspector, Arnold had opportunity to compare the workings of the French government with that of Britain, and he tried to persuade his countrymen to adopt the centralised control systems of the former. As an administrator, he was intimately familiar with how bureaucracy could provision and regulate a social sector. His was a world of commissions of inquiry and official reports, assessments of collective action, analyses of public benefit, all sounding a note of national purpose. Arnold made culture central to the modern state's self-identity, and after him it fixes as a point of civic address. There is a direct line of influence from his writings in the 1860s, to the economist JM Keynes' calls for government intervention in the cultural sector eighty years later, or our own 'Nugget' Coombs' push for a national arts infrastructure in Australia after World War II.

Arnold was not an isolated thinker. But his idea of culture has this notable feature: that it exists in orbit from its own historical reality, hived off from the art-critical discourse which defined the area hitherto, transposed into a serviceprovision language with the loosest aspirational aim. Our 'best self'. What could be more compelling yet indistinct? It is tendentious to say Arnold's idea of culture allowed governments to think art without knowing anything about it, but it certainly brought a new vocabulary to bear. Two types of art talk have a remit of common concern but occupy different levels of discursive generality, like prisoners living in the same house but incarcerated on different floors. Yet the service-provision idea of culture cannot exist without some aesthetic reality grounding it. So the two prisoners must talk to each other, tapping out messages in an attempt to arrive at a shared view. Physical proximity suggests this should be easy, but in the absence of face-to-face contact, clear communication proves frustratingly hard to achieve. The tapping of the prisoner on the top floor becomes more insistent. What is the prisoner on the 
bottom floor banging on about? Why are some things deemed culture and not others? What benefits do they accrue and how are these demonstrable in a top floor way? The whole conversation suffused with a purpose at once lofty and lacking in political contour, culture now the container for all the feelings our benighted, rushed, materially infatuated lives leave out, a White Man's Dreaming, a heady mixture of hope and soap, of who we think we ought to be and what we think we ought to like, as we commune with what Arnold called, in another hazy phrase, 'the best which has been thought and said in the world' (6). The application of this new operational category now in the hands of officially-salaried, centrally-run administrators, who are both the best executive instrument for the new middle class state, and a professional embodiment of it. After Arnold, culture is less about specific qualities - skill, honour, fun, distraction, religious imagery, political message - than general forces, what he called 'powers'. Culture is both a way of harnessing a nation's powers, and a power in its own right. But we should not think of him as a proto-fascist. His conservatism was of the mild, centrist variety, culture a means of softening the brutal expressions of industrial capitalism and more equitably spreading its wealth. As Arnold told it, everyone was a winner from his new line of thinking. This is important because it is easy to cast cultural policy in a baleful light, to see it as ill intentioned or fundamentally flawed, an exercise in national vanity or self-indulgence. Arnold, whose vision was a tragic one, as anyone who knows his poetrycan attest, was nothing if not sincere. His legacy to cultural policy is just this: an asphyxiating sincerity, as the state in elephantine manoeuvre tries to follow the mercurial trajectory of creative practice, indifferent to its specific means, yet convinced it wants the same general ends:

But often, in the world's most crowded streets, But often, in the din of strife, There rises an unspeakable desire

After the knowledge of our buried life;

A thirst to spend our fire and restless force

In tracking out our true, original course;

A longing to inquire

Into the mystery of this heart which beats

So wild, so deep in us - to know

Whence our lives come and where they go. (Arnold 2013)

Only a Victorian sage could take this moving existential question and answer it in the brass argot of utilitarian public policy.

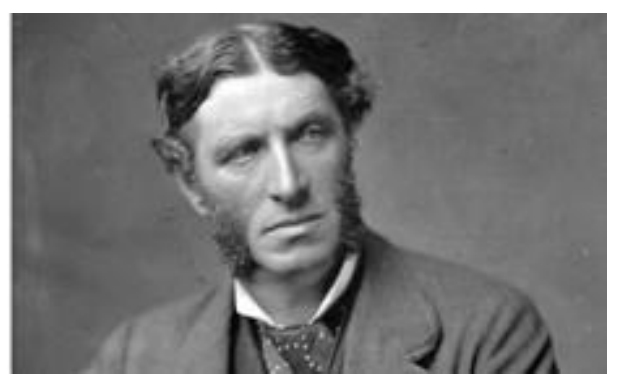

Figure 5. Matthew Arnold

Why reference Arnold? Why raise the image of this particular life? Of a man overshadowed by his father; who spoke six languages; who found inspecting schools depressing and the sight of impoverished children confronting; who grew mutton chop whiskers; who died of heart failure running to meet his daughter off a Liverpool liner? Again, it is to warn that culture is not nature, that the sector is determined by human actions not systemic laws, either God- 
given or market-derived. Or at least it is at times of decision, when choices matter. Arnold stood on the cusp of major political change, when power was moving from one class to another, one type of government to another. $\mathrm{He}$ constructed an idea of culture to suit that change, and we are living with the consequences. I also want to provide an intellectual pedigree for culture as a synthetic category of public policy, to show why this domain is quite different from media, academic and professional ones. For the heart of policy-making is resource distribution and this means government involvement in the sector has a potentially massive effect. Whether we are talking about negative sanctions or positive instruments, the appending of a service-provision discourse to activities previously defined by an art-critical one changes the coefficient of power in the sector as a whole. This language can neither be ignored nor coopted because, post-Arnold, it exists parasitically, fixed on activities whose outcomes are of strong interest, but whose shape, weight and inner meaning is a matter of official indifference. I am not suggesting than policy makers themselves are indifferent to these things. What I am saying is that, to the extent that modern democratic states have constructed a functional model of culture, it is one bereft of historical and spiritual coordinates. Its soul lying outside its body, this fosters a chronic estrangement from the field, and a neverending anxiety about the status and effectiveness of its interventions.

Explanation has long been with the arts. But since modern governments appeared on the scene it has acquired a new centrality. We are living in the wake of a Discursive Big Bang, and this affects us all, whatever our respective domain.

So far I have focussed on language, on the semantic workings of the rhetorical economy. Are there consequences for culture beyond grappling over words and their exact meanings? Unfortunately, yes. Conduct this thought experiment. Imagine you have lost your favourite pair of shoes. You've had them for a number of years and really like them. Fortunately, the government has heard about your plight, and offers you replacement shoes close in type to your original pair. How do you feel? My guess is most of us would feel pleased. Now imagine you have lost your best friend. You've known them for a number of years and really like them. Again, the government hears about your loss and offers to supply a person similar to the one who has recently departed. How do you feel then? Probably most people would say the question is nonsensical. You cannot source friends in a functional way, because friendship involves a singular commitment that cannot be transferred to another person willy-nilly, however alike those people might be in general trait. Shoes are replaceable but best friends are not. Thus the issue is: are cultural experiences like shoes or like best friends?

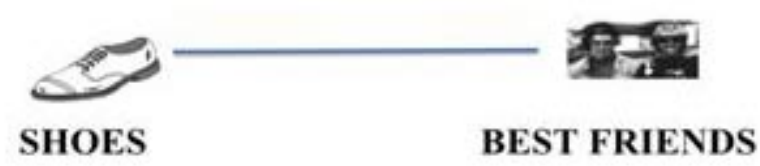

Figure 6. Scale of Value: 'Shoes' versus 'Best Friends'

We might imagine a calibrated scale, with culture-as-shoes down one end and culture-as-best-friend up the other, and degrees of what economists would call substitutability and actuaries fungibility in between. These terms refer to the propensity of a good or a service to be re-statable in properties other than its own nature, whether that restatement comprise another good or a service - 'I'm sorry, we don't have any shoes, what about a hat?' - or a compensatory amount 
of money - 'here's a cheque, buy yourself something nice'. Think about the creative activities we engage in, either as patrons or creators, and you will see a scale of value of this kind produces highly idiosyncratic preference curves. I do not rate popular culture exhibitions very highly. But going to a Supernova Convention with my nine year-old son was a wonderful experience, his preferences over-determining mine in this instance. I like Ibsen's dramas very much, especially Enemy of the People. But I have my own views about this play, so the acclaimed-excellence of the Schaubühne production at the 2012 Melbourne International Festival did not induce me to see it. Adding a temporal axis complicates things even further. What about the sexist, racist, patronising Enid Blyton novels I read when I was young, but which ignited my literary interests such that I can now look back on Blyton's novels as sexist, racist and patronising? In 1880, the paintings of Vincent van Gogh were worthless. In 1990 his Portrait of Dr. Gachet sold for \$82.5M. In 1911, Charles Ives' Three Places in New England was unplayable. In 2011, it was one of the most popular inclusions in US concert programming. And so it goes on, with assessments of artistic worth chasing instances of artistic practice that transform in status as they are run to ground, changing what we thought we were after in the first place. Assessing the value of our cultural experiences is one of the most difficult things we do as individuals. How is this task managed at a government level, by official measurement procedures?

By extension from the conception of culture I have just been describing, it isn't. Synthetic policy categories don't have experiences; they have classifiable objects and functions. Their calibrated scale of value is all shoes, recognising no limit to the operations of substitutability and fungibility. Singularity, a category of one, is an inconceivable outcome and therefore an unmeasurable one. You will have heard the refrain 'art's value is subjective'. This needs recasting if we are to appreciate the conundrum of functional cultural provision. For art to have value it demands an encountering subjectivity. Without a personal response, it is hard to see it has any meaning at all, since even its most distal benefits rely on an act of inward reception to begin with. The issue of cultural policy's relationship to creative practice is weaponised by this lack of a human frame of reference. A ceramicist in Perth; a pub poet in Anglesea; a physical theatre in Brisbane; a rock band in Alice Springs; an eisteddfod in regional New South Wales. All these things, and more, are commensurate, replaceable one by the other, and can be taken up, shifted around and abandoned with no greater sense of historical and personal attachment than the category of culture itself makes allowance for, which is to say, no sense of attachment at all. I said that culture's explanation induces visceral emotions. It is this aspect of policy I am thinking of. It is drily referred to as 'the problem of intrinsic value', suggesting it a problem like other problems, a problem among many problems. It is nothing of the kind. It is the problem for government conceptions of culture and its consequence is a de facto liquefaction of all creative practices and their extrusion through descriptive registers that deprive them of the very features that, on a human level, give them value to $u s$, the only kind of value in culture that matters. Another way of saying this is that preferences in cultural markets do not exist prior to their satisfaction, as classical economists suppose, but come into being through the operation of those markets which are informed by factors other than a desire for Pareto optimality. Policy measures of cultural value are both intellectually controversial and professionally fateful. They are where the politics of culture are now to be found.

Am I suggesting all art is so unique it defies any kind of general explanation, that cultural policy in and of itself is a flawed enterprise? No. Art has an aggregate dimension to it and this can be legitimately addressed without betraying the singular experiences it gives rise to. This dimension, however, is 
art form specific. For example, in drama there is the observable phenomenon of clustering. At any one time, individual dramas will converge in theme, style, character type, narrative shape and so on. Buffy the Vampire Slayer appears and before you know it, there are a number of other TV shows spinning a similar self-conscious, cross-genre formula. This is not just fashion, though fashion enters into it. It is how individual artworks exploit social context, using the information stored in the public imagination to leverage the temporal resources allotted them. These heuristics, or figures of knowledge as the Academy might call them, are shared throughout an art form. The aggregate and singular dimensions of culture then coalesce to achieve greater impact. Shakespeare was an unparalleled creative talent. He was also an Elizabethan playwright, one who shared a territory of formal aesthetic possibility with writers like Marlowe, Jonson, Fletcher, Middleton and Kyd. Take away his collaborators and competitors and you take away his unique contribution. I might go further. As a director who specialises in the development of new drama, I could show in detail how plays and performances make use of aggregate devices to achieve their singular impacts. Know-how like this is helpful in an intervention aimed at improving the quality of a cultural experience, the intrinsic value of a film or a television drama. But you have to know something about how films and television are made, about their respective 'artworlds', as the sociologist Howard Becker calls them (Becker 2008), the relations between creative artists and support personnel, production and distribution, established values and maverick experiments. You have to participate in the art-critical discourse, putting your mouth where your money is, defending your judgements by a displayed awareness of the field. [3]

Government cultural policy in Australia has too often taken an opposite tact. Many of the major federal reports in the area, the Industries Assistance Commission's Inquiry into the Performing Arts in 1976, the McLeay Report ten years later (House of Representatives Standing Committee on Expenditure 1986), the Nugent Report the decade after that (Major Performing Arts Inquiry 1999) and the 2012 review of the Australia Council, have been spearheaded by non-arts professionals. Practitioners are seen as the problem, their words and perspectives framed as self-interested and self-serving. Cultural policy, like the category of culture itself, has been an outsiders' construct, developed at a distance from the knowledge and influence of the sector, lest it be 'captive to its clients', a condoning of the values of the status quo. Such a view is little better than a gloss on ignorance, and the reports I have listed are hobbled by a lack of familiarity with the activities they seek to instruct. The exception is Creative Nation, which Paul Keating commissioned in 1993 as a thank-you to Australian artists for getting his government re-elected. But as this lacks an operational plan, it suffers from the opposite problem: the right intentions, but no real targets. The failure here is one of cultural leadership. A book like Justin Macdonnell's Arts, Minister? (1994) makes dismal reading. If our ministers for agriculture knew as little about food production as some of our ministers for the arts have known about art, the country would starve to death.

Cultural policy is possible, then, but in Australia has not been done well. Historical knowledge is key to critical awareness, which is key to a fit between panoptic government categories and given creative practices. By 'creative practices' I mean not only the traditional arts but anything that can be considered an aesthetic activity. If synthetic notions of culture are to have real application - if we are to have, for example, a national cultural policy - then of course it should recognise an equality of potential value over a range of creative pursuits. A visit to the opera can be awful and a night ten-pin bowling just dandy. Arguments about the relative merits of high versus popular art forms should not distract us from ensuring public policy takes hold of the reality of culture on a level of intrinsic meaning and not just extrinsic effect. 
And this means disciplining language and the use of key terms. If governments are going to stay in the art-making game, their talk needs substantial renovation, and this is true whatever the object of attention because what I am saying is that policy and its progeny - reporting, measurement, governance, compliance, acquittal - are deaf to the features they should be most alive to, as a matter of both political inclination and historical skew.

\section{Where to From Here?}

If cultural value presents subjectively can it be measured in an aggregate way at all? In 2006, the policy analyst John Holden put out an influential booklet containing a triangular diagram that showed three generative nodes of cultural action: practitioners, policy-makers and the public (Holden 2006). The implication is that value is relational, created in dynamic interplay between these nodes. Holden's diagram is reminiscent of one by Hillman-Chartrand and McCaughey, published in 1989, suggesting something similar, although in that case the nodes are: artists, artworks and audiences. I published one too in 1996, in a more ironic vein, my three nodes being: arts bureaucrats, arts administrators and arts academics.

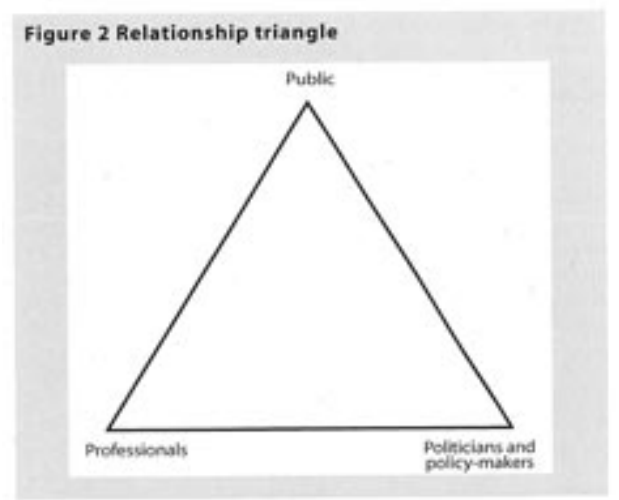

FIGURE 1.-Value Grid

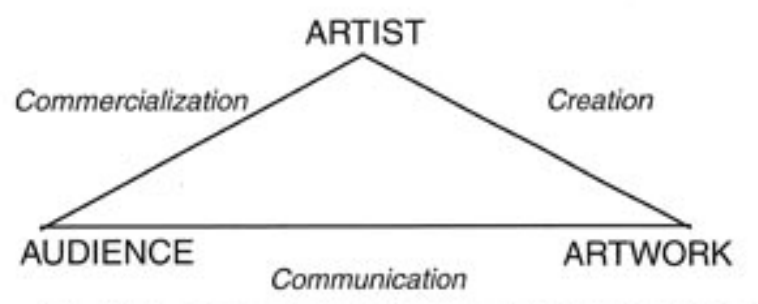

Souvce. Hallman.Chartrand, Harry, and Claire McCaughey. 1969. The Arm's Length Principle and the Arts: An International Perspective. In Who's To Pay for the Arts? Ed. Mition C. Cummings Jr, and J. Mark Davidson Schuster. Neww Yorki ACA.

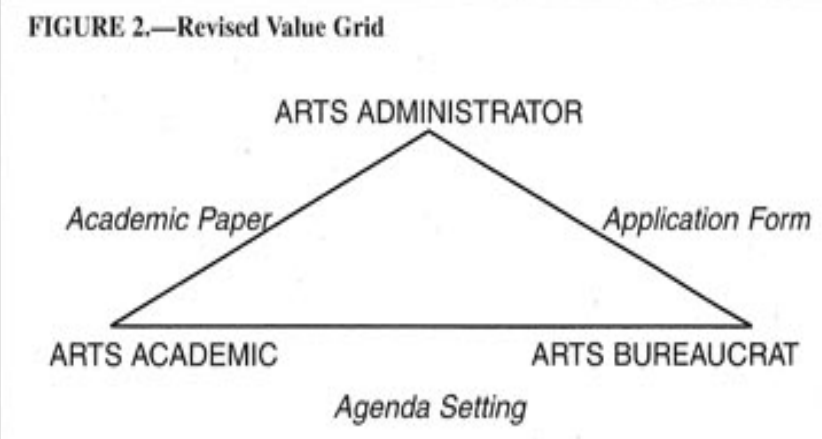


Figures 7, $8 \&$ 9. Left to right: diagrams from Holden's Cultural Value and the Crisis of Legitimacy,

Hillman-Chartrand and McCaughey's 'The Arm's Length Principle and the Arts', and Meyrick's 'Accounting for the Arts in the 90s' (Meyrick 1996)

It is possible to combine and recombine the ingredients of cultural value without getting any closer to how they actually cook up. All these diagrams outline a Bermuda triangle where something happens in the middle that defies formularisation. In its foundationally unstable condition, cultural policy lurches from node to node in the belief that one or the other determines the health of the entire system. For the Elizabethan Theatre Trust, the cultural agency that preceded the Australia Council, value was created by arts institutions; for the Industries Assistance Commission it was audiences; for the Rotherwood Plan (1982) it was artists; for Creative Nation it was the country itself; and for the Nugent Report it was institutions again. There is no simple answer to how cultural value arises, and thus how it can be measured. But it is capable of better management, analytically and politically, provided we are honest about the current situation. Modern democracies do many things well. Cultural provision isn't one of them. The evidentiary processes governments use to define and inform their regulation of social activities do not work well for culture, are forever contracting the area into a corner of itself, losing that affective, personalised connection so vital to successful intervention. It is for this reason the UK cultural historian John Pick in The Arts in a State (1988) suggests cultural policy is better implemented by empowered impresarios than by administrative committee. The implication is that measuring cultural value is a waste of time. Judgement, not data, governs the operation of the category of culture, always has, always will.

I have a lot of time for Pick, though his cranky later publications are less nuanced than his earlier work [4]. However, just because you cannot answer one type of question does not mean you cannot answer another. The arts are susceptible to alternative interrogation that expands views of its outcomes and leads to a better estimation of the so-called 'the triple bottom line'. I am talking about changing what the policy domain considers data, by triangulating qualitative accounts with quantitative methods that exacerbate the bucket-witha-hole idea of culture they supposedly inform. That sounds very methodological, and it is. But it has very real consequences. Another question to ask about the arts is, who takes the risk? If cultural value is the result of cultural actions, and these actions represent an investment of time, money and commitment, who makes that investment, and who loses out when it does not come off?

On December 17th, 1895, the day before the premiere of their next production, The Silence of Dean Maitland, Arthur Dacre and Amy Roselle returned to their lodgings in Macquarie Street where Amy took a sleeping draught and lay on the bed with a handkerchief over her eyes. Arthur then shot her twice through the heart before turning the gun on himself. Discovering he had run out of bullets, he slashed his throat with a razor and died in agony on the floor. They were buried in Waverley cemetery where their headstone reads, 'they loved each other and in death they were not divided'.

If we could go back to that terrible afternoon what would we say to Arthur and Amy to make them change their minds? When their show opened, it was a great success, and ran for a month. Arthur and Amy illustrate a fact cognate to all creative practices, high or low, commercial or non-commercial, collaborative or individual, traditional or emergent: that they are the product of 
human actions that can go gloriously right or disastrously wrong. The specific situations in which they are produced, therefore, their industrial and institutional configurations, need to be respected. Their historical modes of delivery, the art forms, need to be understood and appreciated in their particular development, aims and tensions. One way of looking at cultural policy, a more positive one than I have allowed for thus far, is that it makes different kinds of explanation possible. The media, academic and professional domains are not sacrosanct, nor is the art-critical discourse that defines them. They did not do much for Arthur and Amy at any rate, and the introduction of government subsidy into the cultural sector allows, among other things, a different risk profile for creative activity. It does not eliminate risk but it can cultivate better management of it - if cultural policy can address its own conceptual limitations, offset its assessment biases.

Currently, at Flinders University I am part of a small team of researchers from across the humanities, tourism and creative arts areas grappling with just this problem. The relationship between words and numbers in the rhetorical economy is my particular focus. Before I went into the theatre I trained as a political economist. So I am not adverse to figures. I use them in my own research and appreciate their illocutionary force when properly marshalled. The Cultural Ministers Council Statistical Working Group has no greater fan than me, and its reports contribute greatly to understanding the economic impact of cultural activity in Australia today, which is a massive 3.6\% of GDP (by comparison agriculture is 3.9\%). Quantitative measurement methods are not the problem. The problem is lack of a ground in policy conceptions of culture that sees these numbers read not against social and historical reality but against a non-specific, ever-changing sense of Arnold's 'best self'. This is freeing, up to a point; beyond it, it is ill informed, vainglorious and counter-productive. It also feeds a rank instrumentalism. Numbers are read against other numbers in a downward spiral of synecdochic contraction, institutions reduced to strategic plans, strategic plans to outputs, outputs to numbers, all which are revisable, discard-able, substitutable if results don't meet comparative benchmarks. I am aware I am describing the disease of our times, rational-utilitarian logic run amok. Culture is hardly unique in contracting this, but it is uniquely affected. At no other point in the history of government cultural provision has the sector been so in need of the resources of critical reflection. In an age of Parody Capitalism, when the goal of growth has become a talisman warding off the reality that finite resources cannot be infinitely exploited, culture finds itself fed into specious official algorithms fixated on toxically extrinsic ends. Some analysts would say this is unavoidable. I say it is a retreat from the politics of art, a refusal to deal with the problem of cultural value, and a collapse of cultural policy into little more than a delivery mechanism for the KPIs and centrally determined compliance targets.

So what now? The other day I made a 'to do' list for anyone interested in renovating the unholy relationship between cultural policy and creative practice. I noted:

- The need to disentangle the language of cultural analysis from cultural advocacy, and to avoid the misuse of numbers for tendentious ends (what WJ Reichman in The Use and Abuse of Statistics (1964) calls 'statisculation') [5];

- The need to clarify the origin and motivation of reporting and accountability changes in the policy domain. ('Efficiency savings', are savings for the government, not necessarily for the sector);

- The need to introduce more 'etic' terms and categories into policy service provision discourse, to get governments to display better awareness of art form histories and art-critical discourse; 
- The need to clarify the status of judgements in the policy domain - who makes them, how and why? - given the lack of a 'ground' in official conceptions of culture;

- The need for 'push back' in the policy domain by artists and cultural organisations, the more vigorous assertion of professional experiential vistas. (Who's taking the risk in the creation of cultural value anyway? And where's our theory of the state?)

This is a confronting list of issues, one that goes to the heart of the problem of functional cultural provision. They are not susceptible to easy or immediate solution. But they all involve language. Numbers are a kind of language; so are words. To get these two descriptive registers aligned is of paramount importance, and the best thing artists and cultural organisations can do in this respect is to talk directly and simply about what they do. The need is not for more information but for better information; for explanations shorn of the desire to entrench market positions, or advertise compliance with policy targets. There is a need to talk about art truthfully, specifically and without more bias or boost than can be helped. I imagine a purging of the rhetorical economy, whereby all domains express their views in language that is precise, concise and veracious. I would seek to neither deplore nor valorise particular commitments but to frame them. I would admit particular perspectives but note the ultimate interdependence of the four domains. No one will get out of my purge everything they would like. Artists will not get an endless supply of money, an upfront approval of everything they do. Governments will not get easy proof of cultural value, a set of numbers indicating exact return of social benefit. And critics and academics will have to take more responsibility for managing relations between the service-provision discourse and the art-critical one, ensuring that the key terms taken up in talk about culture have substantive meaning and empirical purchase - keeping both artists and government honest.

Does culture need explaining? Not always, of course, but at key moments, yes. For instance, when we stand to lose something we find we truly value. Under normal circumstances most people's relationship to culture is not intense. Will I go to a film tonight or stay in and watch TV? Will I visit that exhibition I read about in the papers? Will I spend the afternoon at the races? Not earthshattering choices. But when these are threatened, it is a different matter. Having been critical of government involvement in culture, I will finish with an opposite example. In 1942, Australia was at war with Japan. Singapore had fallen and fighting in Papua and Timor was going badly. There was real fear of invasion and John Curtin, the Prime Minister, was caught in a morass of geopolitical and military dilemmas. Yet he chose this very moment to write the introduction to a volume on Australian culture:

At a time when Australia is engaged in fighting for her very existence, The Studio is paying our country the tribute of devoting an issue to Australia's contribution to the arts. No time could be more opportune for drawing attention to the cultural development of the Commonwealth... In a young democratic nation cultural activities are important as a means of expression of the people. During its early stage the arts are likely to be neglected in the pioneering efforts of settlement. Even forty years ago it was difficult for an artist to practice his profession successfully... [But ] now the arts have awakened in Australia... The Studio is to be congratulated for its achievement in keeping alive an interest in creative arts in the midst of destructive forces. (Curtin 1942: 113) 
Curtin's words are simple but irrecusable. I imagine him at his desk, writing. Worried, harried; the battle of El Alamein still to happen; the temptation of drink. The value of culture never better explained than by a soul in their darkest hour of trial.

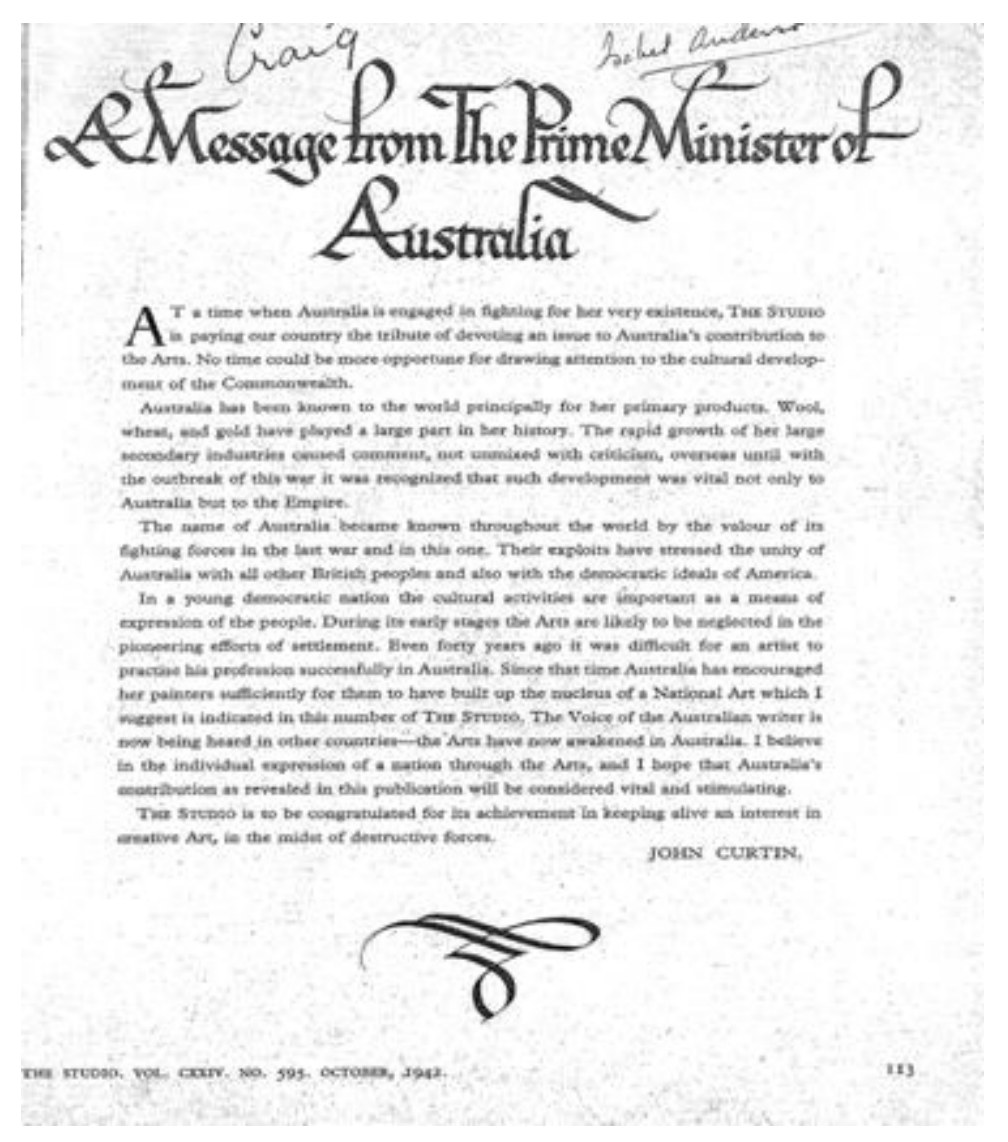

Figure 10. John Curtin's foreword for The Studio arts journal, 1942

\section{Notes}

[1] Culture and Anarchy originally appeared as a series of essays in Cornhill magazine. These were gathered into book form in 1869 and a preface added in 1875. return to text

[2] The exception is Raymond Williams, who devotes considerable attention to Arnold in Culture and Society 1780-1950 (Williams 1963), in a chapter shared with (Cardinal) JH Newman. return to text

[3] This is something Becker himself does well, not only because he was a jazz player but because the ethos of the Chicago School of sociology of which he is an alumni is concerned with just this sort of low-flight knowledge. Artworlds is an arts-sensitive sociological text, showing how culture can be treated as a general category of analysis without losing empirical detail. return to text

[4] Compare, for example, the measured, though still critical Managing the Arts? The British Experience (1986) with the one-eyed Vile Jelly: Birth, Life and Lingering Death of the British Arts Council (1991). return to text

[5] The issue of the use and abuse of statistics in arts reporting is taken up by Eleonora Belfiore in her trenchant 'On Bullshit in Cultural Policy Practice and Research' (Belfiore 2010). return to text

\section{Works cited}


Allott, K (ed) 1954 Matthew Arnold: A Selection of his Poems, Penguin, Harmondsworth return to text

Arnold, M 2013 [1852] 'The Buried Life', Poetry Foundation:

www.poetryfoundation.org/poem/172841 (accessed 23 April 2013) return to text

Arnold, M 1987 [1960] Culture and Anarchy, Cambridge University Press, Cambridge return to text

Becker, H 2008 [1982] Art Worlds, University of California Press, Berkley, Los Angeles \& London return to text

Belfiore, E 2010 'On Bullshit in Cultural Policy Practice and Research', Variant 37 (Spring/Summer): 6-10 return to text

Bharucha R 1988 'A View from India', Economic and Political Weekly 23, 32 (6 August): 1642-1647 return to text

Creative Nation 1994 Department of Communications and the Arts, Canberra return to text

Curtin, J 1942 'A Message from the Prime Minister of Australia', The Studio CXXIV (October): 595 return to text

Eliot, TS 1948 Notes Towards a Definition of Culture, Faber \& Faber, London return to text

Hillman-Chartrand, H \& C McCaughey 1989 'The Arm's Length Principle and the Arts: An International Perspective', in MC Cummings Jr \& JM Davidson Schuster (eds), Who 's To Pay for the Arts? ACA, New York return to text

Holden, J 2006 Cultural Value and the Crisis of Legitimacy, DEMOS, London return to text

House of Representatives Standing Committee on Expenditure 1986 Patronage, Power and the Muse: Inquiry into Commonwealth Assistance to the Arts (The McLeay Report), Australian Government Publishing Service, Canberra return to text

Industries Assistance Commission 1976 Report on the Performing Arts, Australian Government Publishing Service, Canberra return to text

Macdonnell, J 1992 Arts, Minister? Currency Press, Paddington, NSW return to text

Major Performing Arts Inquiry 1999 Securing the Future: Final Report (the Nugent Report), Department of Communications, Information Technology and the Arts, Canberra return to text

McCallum, J 1981 'Some Preoccupations of Australian Theatre Criticism 1955-1978', University of NSW, unpublished MA thesis return to text

Meyrick, J 1996 'Accounting for the Arts in the 90s - The Growth of Arts Administration in Australia 1975-1995', Journal of Arts Management, Law and Society 26, 4: 285-308 return to text

Meyrick, J 2002 See How It Runs: Nimrod and the New Wave, Currency Press, Sydney return to text

Meyrick, J 2010 'Letter to the Field: On The Birthday Party and Cross-Racial Casting Controversy', Contemporary Theatre Review 20, 1: 133-137 return to text

Palmer, I 1979 Matthew Arnold: Culture, Society and Education, Macmillan, South Melbourne, Vic return to text

Pick, J 1988 The Arts in a State, Bristol Classical Press, Bristol return to text

Pick, J 1986 Managing the Arts? The British Experience, Rhinegold, London return to text

Pick J 1991 Vile Jelly: Birth, Life and Lingering Death of the Arts Council of Great Britain, Brynmill, Denton return to text

Reichman WJ 1964 The Use and Abuse of Statistics Penguin, Harmondsworth return to text 
Review of the Australia Council 2012: http://cultureartsgovau/sites/default/files/australiacouncil-review/australia-council-review-reportpdf (accessed 6 January 2013) return to text

Rotherwood Plan 1982 Theatre Board, Australia Council, Sydney[?] return to text

Strachey, L 1959 [1918] Eminent Victorians, Collins, London return to text

Throsby, D 2003 'Determining the Value of Cultural Goods: How Much or How Little Does Contingent Valuation Tell Us?', Journal of Cultural Economics 27: 275-285 return to text

West, J 1978 Theatre in Australia, Cassell Australia, Stanmore, NSW return to text

Williams, R 1963 Culture and Society 1780-1950, Penguin, Harmondsworth return to text

Young, GM 1977 [1936] Portrait of an Age: Victorian England, Oxford University Press, London, New York return to text

Julian Meyrick is Professor of Creative Arts at Flinders University, an Honorary Associate at La Trobe University and an Honorary Fellow at Deakin University. He was Associate Director and Literary Advisor at Melbourne Theatre Company 2002-2007 and kickhouse theatre artistic director 19891998. He has directed many award-winning theatre productions, including Angela's Kitchen, which he co-authored and which attracted the 2012 Helpmann for Best Australian Work. Productions for fortyfive Downstairs: Whiteley's Incredible Blue, Do Not Go Gentle...; for MTC: Tribes, The Birthday Party, Thom Pain, Enlightenment, The Ghost Writer, A Single Act, Cruel and Tender, Dinner, The Memory of Water, Blue/Orange and Frozen; for STC: The Vertical Hour, Doubt and The Snow Queen; for the Griffin: Angela's Kitchen and October. He was director of Who's Afraid of the Working Class? and winner of the 1998 Green Room Award for Best Director on the Fringe. He was a founder member and Deputy Chair of PlayWriting Australia. He has published a history of Nimrod Theatre, See How It Runs (2003), a history of MTC, The Drama Continues, a Platform Paper, Trapped By the Past, and articles on Australian drama, the theory-practice nexus, and contemporary dramaturgy. He is currently completing a book on Australian theatre in the 1980s focusing on the relationship between cultural policy and creative practice.

\section{TEXT}

Vol 17 No 1 April 2013

http://www.textjournal.com.au

General Editor: Nigel Krauth. Editors: Kevin Brophy \& Enza Gandolfo text@textjournal.com.au 